\title{
M. tuberculosis enhances its virulence during replication in blood from HIV patients
}

\author{
Michelle B Ryndak', Krishna K Singh ${ }^{1}$, Zhengyu Peng ${ }^{2}$, Hualin Li ${ }^{3}$, Lu Meng ${ }^{2}$, Suman Laal ${ }^{1,4^{*}}$ \\ From 2nd International Science Symposium on HIV and Infectious Diseases (HIV SCIENCE 2014) \\ Chennai, India. 30 January - 1 February 2014
}

\begin{abstract}
Background
Mycobacterium tuberculosis and HIV act synergistically to enhance and accelerate the development of tuberculosis and progression of HIV infection to AIDS. Hematogenous dissemination of $M$. tuberculosis leading to extrapulmonary $\mathrm{TB}$, disseminated $\mathrm{TB}$ and miliary $\mathrm{TB}$ is greatly increased in HIV+ TB patients. We have compared the transcriptome of $M$. tuberculosis replicating in whole blood from immunocompetent and immunodeficient individuals to understand how $M$. tuberculosis adapts to the blood environment during hematogenous dissemination.
\end{abstract}

\section{Methodology}

Whole genome microarray analysis was performed on RNA from $M$. tuberculosis replicating in whole blood from PPD negative HIV - healthy donors and HIV+ donors. Genes with a fold change of $\geq 2$, at a false discovery rate of $<2 \%$, were considered significantly differentially expressed.

\section{Results}

M. tuberculosis survives and replicates in blood, and enhances its virulence/pathogenic potential during adaptation to the hematogenous environment. The blood specific transcriptome reflects suppression of dormancy, induction of cell-wall remodeling, alteration in mode of iron acquisition, evasion of immune surveillance and enhanced expression of important virulence factors that drive active infection and dissemination. Compared to replication in HIV blood, these changes are accentuated during replication in blood from HIV patients. The expression of ESAT-6, known to play an important role in dissemination of $M$. tuberculosis from the lungs, is

\footnotetext{
* Correspondence: Suman.Laal@nyumc.org

${ }^{1}$ Veterans Affairs Medical Center, New York Harbor Health Care System, New York, NY, USA

Full list of author information is available at the end of the article
}

upregulated in M. tuberculosis growing in blood, and especially dramatically during growth in HIV+ blood.

\section{Conclusion}

M. tuberculosis modulates its aggressive progression to disseminated forms of TB by modifying its transcriptome to acquire a phenotype with enhanced virulence that favors active infection and dissemination.

\section{Authors' details}

${ }^{1}$ Veterans Affairs Medical Center, New York Harbor Health Care System, New York, NY, USA. ${ }^{2}$ Institutes of Biomedical Sciences, Shanghai Medical College, Fudan University, Shanghai, China. ${ }^{3}$ Center for Virology and Vaccine Research, Beth Israel Deaconess Medical Center, Harvard Medical School, Boston, MA, USA. ${ }^{4}$ New York University Langone Medical Center, Departments of Pathology and Microbiology, New York, NY, USA.

Published: 27 May 2014

doi:10.1186/1471-2334-14-S3-012

Cite this article as: Ryndak et al:: $M$. tuberculosis enhances its virulence during replication in blood from HIV patients. BMC Infectious Diseases 2014 14(Suppl 3):012.

Submit your next manuscript to BioMed Central and take full advantage of:

- Convenient online submission

- Thorough peer review

- No space constraints or color figure charges

- Immediate publication on acceptance

- Inclusion in PubMed, CAS, Scopus and Google Scholar

- Research which is freely available for redistribution

Submit your manuscript at www.biomedcentral.com/submit
C Biomed Central 